\title{
Development of Propagation Administration according to Buddhist Educational Administration for Buddhist Temples in Bangkok
}

\author{
Phrakhrupalad Sangwan Devasaro (Srisuk) ${ }^{1}$,Phrakhrusangharak Chakkit Bhuripanyo*2, Peravat \\ Chaisuk $^{3}$, Thongdee Sritragarn ${ }^{4}$ \\ 1,2,3,4 Faculty of Education, Mahachulalongkornrajavidyalaya University \\ 1,2 dews280@ hotmail.co.th, ${ }^{3}$ pchaisuk@gmail.com ${ }^{4}$ thongdee.sri@mcu.ac.th
}

\begin{abstract}
This research aimed 1) to study and analyze the propagation administration status according to the Buddhist educational administration of temples in Bangkok, 2) to study the propagation administration model according to the Buddhist educational administration for temples in Bangkok, and 3) to present a model of propagation administration according to Buddhist educational administration for temples in Bangkok. Action research and qualitative research were used for research design. Data were collected both qualitative data and quantitative data that related to conceptual framework by interview 10 key informants, focus group discussion with 10 experts, and survey 224 sample using questionnaires. The research results were found that 1) the status of the propagation administration according to the Buddhist educational administration of temples in Bangkok with SWOT analysis of strengths, weaknesses, opportunities and obstacles were found in the principles of (1) the development of the management model, (2) the planning model, (3) the organization model, and (4) the propagation model according to the Buddhist principles. 2) The propagation administration model according to the Buddhist educational administration for temples in Bangkok consisted of (1) the status of the propagation administration according to the Buddhist educational administration integration with Buddhist principles and the concept of propagation theory, (2) develop an integrated Buddhist administration model adhere to the principles of Buddhism and modern ideas, (3) planning by connection modern concept and principles of Buddhism, (4) administration and organization for efficiency in a holistic manner, and (5) emphasize the Buddhism guidelines for propagation. 3) A model of propagation administration according to Buddhist educational administration for temples in Bangkok consisted of 4 aspects which were (1) Santhasana clarifies and explains the reasons, (2) Samatapana gives advice to value and importance, train the mind, accept and be ready to act, (3) Samuttechana creates motivation, motivation, enthusiasm, encouragement, and build confidence in the heart to achieve success, and (4) Sampahangsana creates emotions aesthetically delight the mind by pointing out its benefits and ways to advance towards success as expected in the future.
\end{abstract}

Keywords

Buddhist Principles, Educational Administration, Innovation

Article Received: 10 August 2020, Revised: 25 October 2020, Accepted: 18 November 2020

\section{Introduction}

The propagation of Buddhism in this form, it will help modern people to access the principles of the Lord Buddha easily, extensively, and quickly. Research studies for the development of the Sangha Council's administration in Bangkok will play an important role in supporting the monks had access to information that would support the betterment of the mission management, including searching for the current status of the Thai monks' missionary management in relation to the missionary approach. Target group management in the propagation of Buddhism allocation of available resources thoroughly setting the value of the principles that should be spread to different levels of missionary work in order to carry out their duties as well as a form of approach to being a movement in the spread of Buddhism along with the development of the Buddhist missionary management model of the Sangha to present to the Sangha has managed the propagation of Buddhism [1]. The current Thai society problem which tends to exacerbate change of the world as Buddhism is a religion of education and self-development which is priceless in Thailand from the past to the present. As the personification of Thai and the Thai nation is inseparable, Buddhism is the best choice to solve social conflicts. Therefore, the Thai Sangha Organization has to play a role in the development of other organizations that must develop their own organization first, and teach others later "(Khut. (Thai) 25/158/81). Therefore, the spread of Buddhism, it is the duty of the monks directly. By using different forms of propagation of Buddhism, adjusted according to suitable conditions mission work has been successful and extensively to ensure the stability of Buddhism. The monks are therefore the core of the Buddhist company that is regarded as having an educational role for the villagers, be a moral teacher, help society to be a leader in community development and fix the problem. Nowadays, if the monks also propagated in a conservative manner. The original pattern that has been practiced before causing the new generation to ignore the temple and reduced the number as well because of the advancement of technology [2].

\section{Research Objectives}

This research aimed 1) to study and analyze the propagation administration status according to the Buddhist educational administration of temples in Bangkok, 2) to study the propagation administration model according to the Buddhist educational administration for temples in Bangkok, and 3) to present a model of propagation administration according to Buddhist educational administration for temples in Bangkok. 


\section{Conceptual Framework}

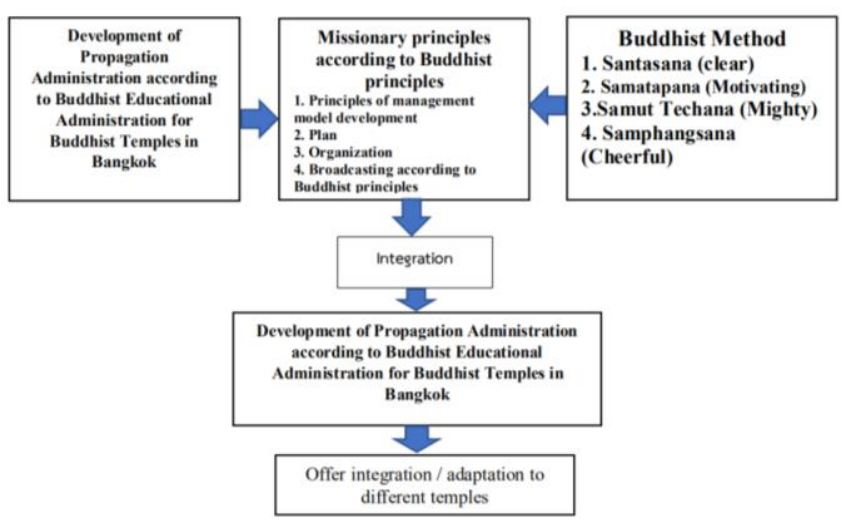

Fig.1 Conceptual Framework

\section{Research Method}

Action research and qualitative research were used for research design. Data were collected both qualitative data and quantitative data that related to conceptual framework by interview 10 key informants, focus group discussion with 10 experts, and survey 224 sample using questionnaires. Research tools were questionnaires, questions for interview and focus group discussion. Qualitative data was analyzed by content analysis whereas quantitative data were analysis by using descriptive statistics consisted of percentage, frequency, mean, standard deviation.

\section{Research Findings}

1. In-depth interviews using the principles of analysis of the propagation administration according to Buddhist principles for educational administration of temples in Bangkok analyze with SWOT based on ideas and interviews and group discussions from experts. There is a consensus as follows:

1) Strengths, strengths or advantages, the organization of the environment, landscape, buildings, places or physical of a temple as a source of the temples in the city are generally featured in ancient sites, antiques, Buddhist arts, fine arts and architecture which is a cultural heritage and valuable learning media suitable for learning about propagating Buddhism and focus on the conservation of natural resources and the environment.

2) Weakness or disadvantage still lacking skilled personnel budget management of the temple and communication technology used as an important tool in disseminating the Dharma Educational materials, tools, materials, inadequate and outdated materials lack of systematic knowledge management and the coordination within the organization is still delayed. It is a weakness of management for temples in Bangkok.

3) Opportunities, Opportunity to take action Building cooperation and the role of the state to promote focus on human development at the center of development into a complete human being with moral knowledge and develop a strong and balanced society of the Sangha.

4) Threats, obstacles, limitations or factors that threaten the operation of the organization. Most of the temples faced the problem of lack of personnel with specialized skills, knowledge, ability and potential in foreign languages, teaching, presentation techniques, using media, and using necessary technology including the propagation budget Should get from the government to support the budget as well [3].

2. A model of missionary administration according to Buddhist principles of educational administration for temples in Bangkok get the following form.

1) Model of propagation by building a network has been in the area to build a network of religious relations by promoting a process of learning about religion by cultivating faith fostering mental stability and livable environments.

2) Planning scheme, the implementation of the plan is the driving process of the propagation of Buddhism absolutely necessary that has to be pushed for attitude change including operating methods for personnel at all levels to achieve recognition and participation and can apply the operations to suit the practice.

3. Form of organization network decentralized organization, such as venue, has the power to make decisions on its own. For the speed of processing relying on the participation of each work segment making the missionary work more convenient [4].

3. To present the model of mission management according to the Buddhist principles of educational administration by integrating with Buddhist teaching methods to spread Buddhism and in order to achieve the achievement of the missionary practice, each time must consist of 4 methods: point out, show, act, urge, awaken, cheerful or bright, motivate, dare, cheerful.

1. Santasana explains it clearly clarify what is to teach, clarify, discriminate, explain and reason clearly until the audience understood clearly, saw it, and saw it as he held his hand to see with his eyes.

2. What should I do or learn to do?, would suggest or describe to appreciate the value saw the importance of practicing and being able to accept and want to do.

3.Samut Techana inspires daring, arousing enthusiasm. Perseverance enthusiastic confident is to make it successful fight work, not afraid, not afraid, tired, not afraid, difficult 4.Samphangs bring to soothe the heart to be refreshed, cheerful, to nourish the mind to be joyful by pointing out the benefits or benefits that will be achieved and the way to progress further to achieve more.

When analyzing the qualitative data to support qualitative data and analyze data about the model of Buddhism propagation administration according to the Buddhist principles the quantitative methods are as follows: 1) the propagation administration according to the Buddhist principles of educational administration, 2) principles of the development of the administrative model, 3) the planning model, 4) the organization model, 5) the propagation model according to the Buddhist principles Find the mean score and the standard deviation appear as the table.

Table 1 Mean and Standard Deviation of Buddhist Principles Data on Buddhist Missionary Administration Model according to Buddhist Principles of Education for Temples in Bangkok Santasana side 


\begin{tabular}{llll}
\hline $\begin{array}{c}\text { Development of Propagation } \\
\begin{array}{c}\text { Administration according to Buddhist } \\
\text { Educational Administration for Buddhist } \\
\text { Temples in Bangkok }\end{array}\end{array}$ & $\overline{\boldsymbol{x}}$ & S.D. & Meaning \\
\hline $\begin{array}{c}\text { Santasana side } \\
\text { 1. Set up the operating process system }\end{array}$ & 4.12 & 0.65 & High \\
2. Implement the work plan & 4.07 & 0.68 & High \\
3. Clarify the operation method. & 4.01 & 0.72 & High \\
4. Follow the various procedures. & 4.01 & 0.63 & High \\
\hline Total & $\mathbf{4 . 0 6}$ & $\mathbf{0 . 6 4}$ & High \\
\hline
\end{tabular}

When considering the information on the Buddhist principles about the Buddhist missionary administration model according to the Buddhist principles of education administration for temples in Bangkok. It was found that the importance was at a high level $($ Mean= 4.06, S.D. $=0.64)$. It was found that the most important aspect was Set up the operating process system (Mean $=4.12, \mathrm{SD}=0.68$ ), implement the plan (Mean $=4.07, \mathrm{SD}=0.68)$ and clarify the operation method (Mean=4.01, $\mathrm{SD}=0.72$ ), various operations $($ Mean $=4.01, \mathrm{SD}=0.63)$, respectively.

Table 2 Mean and Standard Deviation of Buddhist Principles

Data on Buddhist Missionary Administration Model for Buddhist Administration of Education for Temples in Bangkok

\begin{tabular}{llll}
\hline $\begin{array}{c}\text { Development of Propagation } \\
\text { Administration according to Buddhist } \\
\text { Educational Administration for } \\
\text { Buddhist Temples in Bangkok }\end{array}$ & $\overline{\boldsymbol{x}}$ & S.D. & Meaning \\
\hline $\begin{array}{c}\text { Samathapana Side } \\
\text { 1. Be able to describe the }\end{array}$ & 4.02 & 0.61 & High \\
$\begin{array}{c}\text { sequence of operations. } \\
\quad \begin{array}{l}\text { 2. Promote ideas and create } \\
\text { mutual understanding. } \\
\quad \text { 3. Encourage operational }\end{array}\end{array}$ & 4.07 & 0.67 & High \\
$\begin{array}{c}\text { cooperation } \\
\text { 4. Build success and unity }\end{array}$ & 4.23 & 0.78 & High \\
too. & 4.18 & 0.65 & High \\
\hline Total & $\mathbf{4 . 1 4}$ & $\mathbf{0 . 6 7}$ & High \\
\hline
\end{tabular}

When considering the information on the Buddhist principles about the Buddhist missionary administration model in accordance with the Buddhist principles of education administration for temples in Bangkok, in terms of overall smartness, it was found that the significance was at a high level (Mean $=4.14, \mathrm{SD}=0.67$ ) and when considering each aspect It was found that the most important aspect was encourage operational cooperation (Mean $=4.23$, $\mathrm{SD}=0.78$ ), build success and unity (Mean $=4.18, \mathrm{SD}=$ $0.65)$ and promote ideas and create mutual understanding (Mean $=4.07, \mathrm{SD}=0.67$ ). It is able to describe the sequence of operations (Mean $=4.02, \mathrm{SD}=0.61$ ), respectively.

Table 3 Mean and Standard Deviation of Buddhist

Principles Data on Buddhist Missionary Administration

Model according to Buddhist Principles of Education for Temples in Bangkok Samut Techana side

\begin{tabular}{llll}
\hline $\begin{array}{c}\text { Development of Propagation } \\
\text { Administration according to Buddhist } \\
\text { Educational Administration for Buddhist } \\
\text { Temples in Bangkok }\end{array}$ & $\overline{\boldsymbol{x}}$ & S.D. & Meaning \\
\hline $\begin{array}{l}\text { Samut Techana side } \\
\text { 1. Inspire confidence }\end{array}$ & 4.22 & 0.62 & High \\
$\begin{array}{l}\text { 2. Promote according to the ability or } \\
\text { expertise in a specific area to encourage } \\
\text { motivation to work with }\end{array}$ & 4.17 & 0.61 & High \\
$\quad \begin{array}{l}\text { 3. Establish a policy to work } \\
\text { together. }\end{array}$ & 4.23 & 0.68 & High \\
$\quad$ 4. Set goals for success. & 4.28 & 0.76 & High \\
\hline \multicolumn{1}{c}{ Total } & $\mathbf{4 . 2 2}$ & $\mathbf{0 . 6 7}$ & High \\
\hline
\end{tabular}

When considering the information on the Buddhist principles about the Buddhist missionary administration model according to the Buddhist principles of educational administration for temples in Bangkok the overall significance of Samut Techana was found at a high level (Mean $=4.22$, S.D. $=0.67)$. It was found that the most important aspect was Set goals for success (Mean $=4.28$, $\mathrm{SD}=0.76$ ), set a policy for collaboration (Mean $=4.23, \mathrm{SD}$ $=0.68)$ and inspire confidence $($ Mean $=4.22, \mathrm{SD}=0.62)$. Can or specialize in a specific area to stimulate wanting to work with $($ Mean $=4.17, \mathrm{SD}=0.61)$, respectively.

Table 4 Mean and Standard Deviation of Buddhist Principles Data on Buddhist Missionary Administration Model according to Buddhist Principles of Education for Temples in Bangkok Semaphangsana side

\begin{tabular}{lccc}
\hline $\begin{array}{c}\text { Development of Propagation } \\
\text { Administration according to } \\
\begin{array}{c}\text { Buddhist Educational } \\
\text { Administration for Buddhist } \\
\text { Temples in Bangkok }\end{array}\end{array}$ & $\overline{\boldsymbol{x}}$ & S.D. & Meaning \\
\hline $\begin{array}{l}\text { Sampahangsana Side } \\
\text { 1.Improve the workplace } \\
\text { landscape }\end{array}$ & 4.02 & 0.68 & High \\
$\begin{array}{l}\text { 2. Create a collaborative } \\
\text { environment }\end{array}$ & 4.29 & 0.71 & High \\
$\begin{array}{l}\text { 3. Work in a team like a } \\
\text { Kalyanamit } \\
\text { 4. Encourage members to } \\
\text { be happy at work, cheerful } \\
\text { and happy at work. }\end{array}$ & 4.35 & 0.75 & High \\
\hline \multicolumn{1}{c}{ Total } & $\mathbf{4 . 1 9}$ & $\mathbf{0 . 7 0}$ & High \\
\hline
\end{tabular}

When considering the information on the Buddhist principles about the Buddhist missionary administration model according to the Buddhist principles of educational administration for temples in Bangkok as for the overall seminar, it was found that the significance was at a high level $($ Mean $=4.19$, S.D. $=0.70$ ). It was found that the most important aspect was work as a team like Kalyanamit (Mean $=4.35$, S.D. $=0.65)$, create a collaborative atmosphere (Mean $=4.29$, S.D. $=0.71)$ and improve the work site landscape $($ Mean $=4.02$, S.D. $=0.68)$.

The quantitative data study found that respondents were double-opinionated with the qualitative data. It is suitable to be used for temples in Bangkok and in the country through processes and effective management and their effectiveness requires knowledge and understanding of general theory and management principles. In order to apply the knowledge to suit the work situation and environment. The Lord Buddha used both science and arts to manage the organization of Buddhism. His Majesty relies on various administrative processes and resources as a management factor. There are many modern organizational theories that can be successfully applied to manage the organization right now.

\section{Discussions}

1. The model of Buddhist missionary administration according to Buddhist principles of educational administration for temples in Bangkok. The research results were discussed on the results of the study, and SWOT was used to analyze the following points: 1) Strengths, strengths 
or advantages, 2) Weaknesses, 3) Opportunities to take action.

Strengths or advantages are 1) the structure of the Buddhist missionary administration system according to the Buddhist principles of education administration for temples in Bangkok that can drive Buddhism work, 2) have personnel with knowledge and skills, 3) People are interested in participating in important Buddhist activities, 4) Government agencies give importance to and participate in Buddhist activities.

Weaknesses: weaknesses or disadvantages, including 1) limited personnel lack of personnel who are directly responsible for the routine work, 2) Lack of promotion and support from the government in terms of budget management, 3) Budget for work and activities development is small, 4) Lack of modern technology media for the development of Buddhist propagation according to Buddhist education administration principles.

Opportunities for action include 1) The government's plan policy emphasizes the administration of Buddhism, 2) There are monks to work in Buddhist activities covering an area, and 3) Most of the people practice Buddhism.

2. A model of missionary administration according to Buddhist principles of educational administration for temples in Bangkok.

1. The form of propagation of Buddhism, there are various elements of both temples and individuals to become skilled persons, namely learning the principles, concepts and theories of Buddhism, have good knowledge of the language, knowing how to use words to explain, express opinions and Dharma for others to understand and see according to related to the concept [5] has researched "Strategies for propagating Buddhism of the graduates of volunteering on the plateau". The problem of Phra Bundit Asa was lack of personnel because the number of them decreased. Lack of operating budget Lack of management method difficult to reach the host, unable to communicate with villagers in some areas. As for the guidelines for the implementation of the Buddhism propagation strategy of the volunteer graduates on the plateau, it was found that there was a need to enhance the management of the graduate volunteer project facilitate build potential according to the theory of communication, the application of theoretical knowledge to create potential for the application of Buddhist principles and integration for application to suit the local conditions.

2. Plan promote and support the measure to be a learning center and a source of wisdom for the community and there should be a plan to promote implementation especially the monks who perform duties and plan the mission abroad consistent with the concept [6] achievement of Buddhism in the Lisu ethnic group of the Dharma Charik. The results of the research were as follows: 1) The propagation of Buddhist monks in the Lisu ethnic group was slow. Difficulty 2) beliefs and traditional cultures 3 ) the language of communication is not good in speaking, reading and writing Thai and especially "Lisu language". It is a problem for the Buddhist monks. 4) The shortage of Buddhist monks the appropriate approach to the achievement of Buddhism is: 1) there should be a propagation plan or project, 2) the education of the Buddha and the Dharma, 3) the scholarship for the Buddhist monks and novices of Lisu, 4) should be specified. Meaning of training for the lisu Buddhist mandala as for the suggestion of Phra Dharmajakhi, it should emphasize important Buddhist principles and necessary for life such as 5 precepts, Sangkhahavatthu IV, Gharavasadham IV, Four Noble truth, Makkha 8, to change the attitude and vision of the Lisu Nation to meet the true Buddhism principles which will make the propagation of Buddhism more effective.

3. Form of organization There is also a networked decentralized arrangement. Centralized form of power and informal for the speed of processing must manage the organization according to the form of organizational management related to the concept [7] conducted research on "Buddhist propagation management model of the Sangha Governing Organization Part 2", the research found that the monks did not catch up with the world, do not understand the process of social change and the complex problems of society. When going to preach or give lectures to students or intellectuals listening, it will make them look at the monks that no development making it impossible to solve the problems of the villagers and as a cause for him to turn to others. In spite of the role of monks in the past who acted as advisors of the villagers when they had problems in their lives. Technology-product facilities and more modern science such as electricity, radio, television, telephone, car, air conditioner, etc. have been involved with the monks. Monks have to adapt to the conditions of society more, and make people who do not understand the need of the monks to be involved in these things. For confusion with principles, the missionaries were not accurate, giving the principles and insufficient insight to make the learners confused and distracted to diminish the original faith and there was confusion and distraction in the principle that the truth is what is the correct doctrine. Monastic institutions do not have sufficient personnel to propagate accurately and precisely, it inherently means that no personnel with accurate knowledge and understanding of Buddhism is a propagation problem causing Buddhists to confuse misunderstandings and misunderstandings from the truth according to Buddhism.

3. Propose a model of propagation administration according to Buddhist educational administration for temples in Bangkok

In order to achieve success in the mission, it consists of 4 methods: point to point, to act, to incite, to awaken, to be cheerful or to be bright, motivated, to be cheerful, as follows: discriminate, explain and clearly show the reasons until the listeners understand clearly, 2) Smartpana invites you to want to be put into practice recommend or lecture to appreciate the value saw the importance of practicing accept and take action or put it into practice, 3) Samut Techana provokes daring perseverance enthusiastic be confident that you will succeed by pointing out the benefits and ways to achieve further progress. solve the concept [8] on "Model of education management for the propagation of Buddhism on social networks of Buddhist organizations in Thailand".

1) Conditions of use on social networks of Buddhist organizations in Thailand were found. There is an education management to spread Buddhism on social media having the connecting link with the media mix / multi-media to reach the target audience as possible as well as various modern communication technologies. It is the propagation of Dharma 
and public relations activities of the organization. There is an education management to spread the Dharma through twitter, facebook, website, youtube and in the future have expanded channels according to the popularity of society, and has created a propagation area related to Dharma to provide information services to society, individuals, families, organizations, institutions, especially journalism, focus on organizing various activities to provide information and invite to participate in the activities of teaching the Dharma to people of all levels.

2) Model of education management for the spread of Buddhism on social networks of Buddhist organizations in Thailand presented by adhering to the missionary principle of the Buddhism propagation policy by Phrabhrombandit, the president has laid down a 5-item Dharma policy, consisting of (1) fishing outside the home, (2) coordinating ten directions, (3) making friends throughout the yard, (4) Manipulates intelligence, and (5) Salikapon the victim. It was analyzed in conjunction with the $7 \mathrm{C}$ 's theory of effective communication. It is used in communication for the spread of dharma via social media based on 3 principles: approach, understand and reach

3) The researcher concludes the study results from the analysis of the research results and the integration between the 5 Dharma treaching Policy and the 7 Cs Theory. Synthesis is summarized as follows: Leadership, Coordination, Buddhist Knowledge, Buddhist Knowledge Management, Friendly Kalayanamit, Target Group and synthesize the body of knowledge from research before adopting the Buddhism mission management model in accordance with the Buddhist principles of educational administration for temples in Bangkok, need to study that such a model. How perfect and perfect before use the strengths and weaknesses of the model management must also be analyzed. In which Thai people gathered together to build a temple and gave support as well, donate money, make merit, like to go to temples, bring your kids to Sunday Buddhist school. The temple is therefore the center of the community. Conclusion is the body of knowledge from the research results.

\section{Body Of Knowledge From Research}

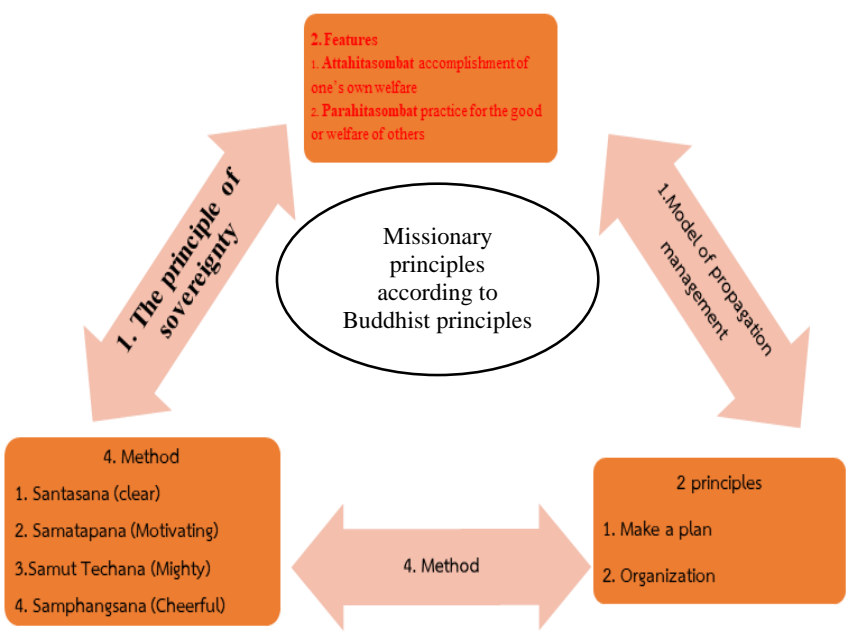

Fig. 2 Development of Propagation Administration according to Buddhist Educational Administration for Buddhist Temples in Bangkok

\section{Recommendations}

\section{Recommendation for policy}

1) The policy of developing a model of propagation of Buddhism should be promoted with the principles of Buddhism and the ability to use the media of the target audience.

2) The government sector should promote the Buddhist missionary administration model in accordance with the Buddhist principles of educational administration for temples in Bangkok for economic, educational, cultural and community contexts in the country by setting a policy of the Sangha.

\section{Recommendation for further research}

1) Should study and research on "gathering knowledge and learning resources in the temple, morality, teachings, knowledge and local wisdom in order to develop a model of dissemination through social.

2) Potential development and promotion of the creation of a model of Buddhism in the era of social crisis.

\section{Conclussion}

Principles of Dharma will achieve the goal that you set or not. Part of the practice comes from without selfcenteredness but use the principle of sovereignty for reasons, truths, righteousness, self-centeredness for the achievement of the goals set. Qualifications, 1) Attha Sombat means the abundance of benefits and benefits to oneself, or things that are the destiny of human life, such as having integrity have the intelligence to be self-sufficient speaking in the present idiom, it is the subject of life, which is the person and the other, 2) the practice of acting for the benefit of others. Propagation management model means to promote the training of the mind and Training the wisdom to realize true intelligence. Principle, 1) Principles of planning Planning is an activity that is expected to be performed, to achieve the purpose achieve objectives, 2) The organization principle is to organize activities for people to practice, to achieve the achievement of the objectives of the job set. Method, 1) Santasana (clear) is to explain the steps of the operation clearly, making it easy for members to follow; 2) Smartasana (motivating) is to explain to understand and agree with the vision. The vision until the faith and the feeling of having to dream far and achieve, 3) Samut Techana (Kaekla) means to inspire self-confidence and enthusiasm in the work of achieving the goal, 4) Samphangsana (Cheerful) is to create an atmosphere of cooperation that will encourage members to be happy in their work.

\section{References}

[1] Phramaha Nong Abphai, "Administration of Buddhism in the globalized era of the Sangha Sangha", Doctor of Philosophy 
Thesis, College of Graduate Studies in Management: Sripatum University, 2012.

[2] Phramaha Boonthin Phunthachotasiri, Buddhism propagation strategies according to the principles of the Four Adventions for the Thai missionaries in Europe, Ph.D. Thesis Department of Buddhist Educational Administration Graduate School: Mahachulalongkornrajavidyalaya University, 2019.

[3] Phramaha Suriya Khababsaenginta, Development of Educational Administration Model in accordance with Buddhist Principles of Educational Administration of Mahayana Monks in Thailand, Ph.D. Thesis, Department of Buddhist Educational Administration Graduate School: Mahachulalongkornrajavidyalaya University, 2019.

[4] Phra Watchara Sangwaro Kasiwat, Conflict Management Strategies in accordance with the Buddhist Principles of Educational Administration for Educational Institutions under the Primary Education Service Area Office, Ph.D. Thesis Department of Buddhist Educational Administration Graduate School: Mahachulalongkornrajavidyalaya University, 2019.

[5] Phramaha Thanundorn Khempanyo, "Buddhist propagation strategy of volunteers on the plateau", Ph.D. Thesis, Graduate School:

Mahachulalongkornrajavidyalaya

University, 2013.

[6] Navin Wongratana Macha. "Achievement of Buddhism in the Lisu ethnic group of Phra Dharmajajik", Dissertation Phuttasadusadee Graduate School, Graduate School: Mahachulalongkornrajavidyalaya University, 2011.

[7] Phrakru Uthai Kitcharak (Surang Sujinno), "Buddhist propagation management model of the Sangha Administrative Organization, Part 2", Ph.D. Thesis, Graduate School:
Mahachulalongkornrajavidyalaya University, 2014.

[8] S. Petchpori. "Model of education management for the spread of Buddhism on the social network of Buddhism organizations in Thailand". Ph.D. Thesis, Graduate School: Mahachulalongkornrajavidyalaya University, 2016. 